\title{
The Status of Educational Input Factors in Junior High Schools in the Central Region of Ghana
}

\author{
American Journal of Education and \\ Learning \\ Vol. 6, No. 1, 50-63, 2021 \\ e-ISSN:2518-6647

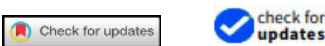

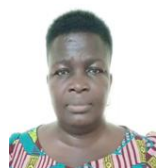

Regina Mawusi Nugba

Department of Education and Psychology, University of Cape Coast, Ghana.

Email: regina.nugba@ucc.edu.gh Tel: +233541530718

\section{ABSTRACT}

Basic education is the core of development and progress in modern societies. It is the level of education that develops the individual's capacity to read, write and calculate. Regardless of this, previous researchers have highlighted the need to improve the state of educational facilities in basic schools in Ghana. After several attempts of educational restructuring and reforms, it is not clear whether the state of input factors have improved. In this study, the current state of input factors in junior high schools (JHSs) in Ghana were surveyed using Central Region as a case. The study further compared these input factors in JHS to find out whether they differed with regards to school context (i.e., rural or urban; private or public). Through a questionnaire and using a stratified random sampling technique, data were obtained from pupils, teachers and headteachers. The study revealed that the input factors in schools were generally not encouraging. Particularly, class sizes and pupiltextbook ratio did not meet the recommended standards by GES. Also, the rate of accessibility or availability of input factors in urban schools were better than in rural schools. Similarly, private schools were found to have better input factors as compared to public schools.

Keywords: Input factors, Class size, Parental involvement, Pupil-textbook ratio, Teaching-learning material.

DOI: $10.20448 / 804.6 .1 .50 .63$

Citation | Regina Mawusi Nugba (2021). The Status of Educational Input Factors in Junior High Schools in the Central Region of

Ghana. American Journal of Education and Learning, 6(1): 50-63.

Copyright: This work is licensed under a Creative Commons Attribution 3.0 License

Funding: This study received no specific financial support.

Competing Interests: The author declares that there are no conflicts of interests regarding the publication of this paper.

History: Received: 6 May 2021/ Revised: 2 June 2021/ Accepted: 28 June 2021/ Published: 14 July 2021

Publisher: Online Science Publishing 


\section{Highlights of this paper}

- Input factors are very necessary to ensure the quality of basic education in Ghana.

- This research explored the state of the input factors in basic education in the country.

- It was concluded that the input factors were not sufficient to improve the quality of education.

- This study is a prompt for stakeholders in education to pay attention to the input factors in basic schools in Ghana.

\section{INTRODUCTION}

Education has become one of the most powerful weapons known for reducing poverty and inequality in modern societies. It is in this regard that the Sustainable Development Goal (SDG) 4 of the United Nations aims to ensure inclusive and equitable quality education. Basic education is the core of development and progress in modern societies. It is the level of education that develops the individual's capacity to read, write and calculate. In other words, it helps to eradicate illiteracy, which is one of the strongest predictors of poverty (Bruns, Mingat, \& Rakotomalala, 2003). Thus, basic education is the only level of education that is available everywhere in both developed and developing countries as well as in urban and rural areas (Akinbote, 2001). This explains why basic education is the largest subsector of any education system and offers the unique opportunity to contribute to the transformation of societies through the education of young ones (UNESCO, 2005).

Despite the relevance of basic education, Ghana has experienced several challenges, in the past, in an attempt to make education accessible to all its citizens (Fobih, Akyeampong, \& Koomson, 1999). The most felt challenge is in terms of infrastructural deficit in rural schools. Pupils in the urban areas have seen many advantages over those in the rural areas in terms of infrastructure, teaching and learning resources, computers and access to the Internet. Again, students in the cities have been exposed to many social and environmental events that make their life far better than the rural pupils as part of the interaction they are exposed to which contribute to the depth of their knowledge and academic performance. Rural schools are often characterised by an inadequate number of teachers, poor classroom structures and, in some cases, schools are under trees. For the schools under trees, it becomes impossible to have lessons during rainy seasons and bad weather. Some rural pupils' study under very dilapidated structures. In a news report, the Upper East Regional Directorate of the Ghana Education Service (GES) expressed worry at the alarming number of schools under trees and those in dilapidated conditions (Ministry of Education, 2016).

In most schools in rural areas, a cloud forming in the sky is a threat to academic work because the schools have to be closed for the safety of the teachers and pupils. The situation causes these schools to lag, especially during the rainy seasons (Ready, 2008; Stufflebeam, 2004). The external distraction of pupils' attention is very high when classes are held under trees as practised in several rural schools. According to the Ghana Education Service policy, an ideal class should be between twenty-five and thirty-five students. When the number of students in a class is more than thirty-five such a class is said to be large (Biddle \& Berliner, 2000; Finn, 2002). It is interesting to note that the number of students in a class in most public Ghanaian Junior High Schools (JHS) in Central Region for that matter Ghana, on average is sixty-five (Zainul-Deen, 2011).

Another challenge associated with holding classes under trees is the size of the chalkboard. The mobile chalkboards are usually very small in dimension, hence cannot contain enough chalkboard illustrations; not to talk of the display of teaching-learning materials (TLMs). It has been observed that the actual teaching and learning time is often affected by weather conditions and by the unattractiveness of the school facilities, particularly in the rural areas. Many of the schools in the more deprived parts of the country have no proper school buildings. For 
example, some schools are still under trees, while a large number of school buildings have leaking roofs and other impediments (Quansah, 2000).

The issue of inadequate teaching and learning materials in the Ghanaian basic schools cannot be overemphasised. Again, looking at the input situation in Ghana, poor infrastructure was cited as a potential cause of low enrollment, higher absenteeism rates and lower teacher motivation (Ministry of Education, 2011). According to the Ministry of Education (specifically, the Monitoring and Evaluation Unit 2011, the range of infrastructure witnessed in the surveyed schools varied significantly, from an underperforming school with no desks for primary one to three (P1-P3) to the performing school which used whiteboards. The survey data, however, did not reveal stark contrasts between classroom furnishing when considered by performance level (Ministry of Education, 2011). Amongst the basic schools surveyed, a larger proportion of performing schools reported sufficient levels of teachers' furniture and pupil furniture; however, the opposite was true for storage cupboards. In contrast to the furniture findings, it does appear to be some disparity in access to amenities at the JHS level. A greater proportion of non-performing JHS lacked access to all amenities whilst at the primary level, a greater proportion of underperforming schools lacked access to clean water and urinals. For any effective teaching to be done, appropriate TLMs and textbooks must be made use of. Virtually, all teachers are willing to use such materials to enhance their teaching but the question is whether these aids are available and adequate. Teaching and learning materials seem to be woefully inadequate in some schools as can be seen in Table 1.

Table-1. Core Textbooks per Pupil in Public Basic Schools (2008-2013).

\begin{tabular}{cccccccc}
\hline & 9-Aug & 10-Sep & 11-Oct & 12-Nov & 13-Dec & Target 2015 & Deprived Dist. \\
\hline KG & $1: 1$ & $1: 2$ & $1: 4$ & $1: 3$ & $1: 3$ & $2011 / 2012$ \\
Primary & $1: 6$ & $1: 6$ & $1: 1$ & $1: 9$ & $1: 2$ & 3 & $1: 3$ \\
JHS & $2: 1$ & $1: 5$ & $1: 9$ & $1: 1$ & $1: 9$ & 3 & $1: 8$ \\
\hline \multicolumn{2}{l}{ Source: Ghana Education Service (2016). }
\end{tabular}

Under the Ministry of Education (MOE) policy, each student in the basic school should have access to three government-designated core textbooks, namely, English, Mathematics, and Science. The textbook ratio of 1:1 means complete individual access to these books. From Table 1, it can be seen that, at the JHS level, the pupiltextbook ratio varies between 2:1 in 2008/2009 to 1:9 in 2012/2013. This means that in 2008/2009 for example, out of the three core textbooks, a pupil had access to only two of the textbooks (2:1). But in 2012/2013, one textbook was shared among nine pupils (1:9). From Table 1, the target for 2015 was every child should have access to the three core subject textbooks. According to the Ministry of Education report (Ministry of Education, 2016), this target was not achieved. Rather, what was achieved was a ratio of 1:6 for Mathematics and English and 1:5 for Science textbooks at JHS in the 2015/2016 academic year. As a result, completion of the syllabus became a problem at grade level leading to a deficit syndrome as noted by Attram (2014) that teachers found it very difficult to complete the syllabi despite their efforts.

Due to the inadequate supply of textbooks and the non-existence of supplementary readers, children essentially go home without any reading materials to read in the evening. It is also common that pupils do not have textbooks at home (Ankoma-Sey, Asamoah, Quansah, \& Aheto, 2019). Attram (2014) confirmed this by stating that due to the deficit syndrome, the syllabi are not completed before the transition of students from one level to another takes place. With respect to teacher quality, according to the Ministry of Education (2016), 71.1\% of teachers at the JHS level in both public and private schools were trained with $28.9 \%$ untrained. The percentage of trained teachers in public JHS schools stood at $89.6 \%$ while that of the private JHSs is $18.7 \%$. However, private school pupils tend to perform better than public schools in the BECE over the years. While the country has, over the years, improved 
upon access to basic education to the citizenry, there are concerns about the quality of the outcome. According to Ampiah (2010) countries that are striving to guarantee all children the right to education have their main focus on access and often overshadowing attention to quality. Yet, quality determines how much and how well children learn and the extent to which their education translates into a range of personal, social and developmental benefits (UNESCO, 2006).

In this study, I attempt to understand the status of input factors in JHS in Ghana, using the central region as a case. The purpose of the study was to evaluate the quality of JHS by assessing the availability of input factors including class size, availability of teaching-learning materials, infrastructure (appropriate pieces of furniture), parental support and adequacy of pupil-textbook ratio in public and private levels of JHS and urban and rural settings in the Central Region of Ghana.

\section{METHODS}

The descriptive survey design was used to carry out the study. This descriptive design was appropriate for this study since this study sought to gather information concerning the current state of educational input factors in public and private JHS. The target population was made up of public and private JHSs in all the 20 Metropolitan/Municipal/District Assemblies in the Central Region. The accessible population was made up of 6 districts (30\%) out of the 20 districts in the Central Region. Two (2) of the districts were selected from the top, middle and bottom purposively making the six districts for the accessible population. In selecting the two districts each, I arranged the 20 districts according to their academic achievement level in the 2015/2016 BECE core subjects (mathematics, English and science) by the Ghana Education Service.

In this study, the sampling units were the schools that were represented by the headteachers, teachers and students. Since it is practically impossible to collect data from all the headteachers, teachers and students within the accessible population of $420 \mathrm{JHSs}$, there was the need to sample a number of the JHSs from each of the districts selected. The schools within the districts were made up of private and public schools and were located within the urban and rural settlements, with most schools located in the rural settlements. The 2010 population census defined rural settlements as settlements with less than 5000 people while urban settlements were defined as settlements with 5,000 or more people (Ghana Statistical Service, 2013).

\begin{tabular}{|c|c|c|c|c|c|}
\hline \multirow[t]{2}{*}{$\mathbf{S} / \mathbf{N}$} & \multirow[t]{2}{*}{ District } & \multirow[t]{2}{*}{ School Type } & \multicolumn{2}{|c|}{ School Location } & \multirow[t]{2}{*}{ Total } \\
\hline & & & Urban & Rural & \\
\hline \multirow[t]{2}{*}{1} & Upper Denkyira West & Public & 5 & 7 & \multirow[t]{2}{*}{14} \\
\hline & & Private & 1 & 1 & \\
\hline \multirow[t]{2}{*}{2} & Upper Denkyira East & Public & 5 & 12 & \multirow[t]{2}{*}{21} \\
\hline & & Private & 3 & 1 & \\
\hline \multirow[t]{2}{*}{3} & Ajumako/Enyan/Essiam & Public & 15 & 10 & \multirow[t]{2}{*}{30} \\
\hline & & Private & 3 & 2 & \\
\hline \multirow[t]{2}{*}{4} & Twifo/Heman/Lower Denkyira & Public & 3 & 10 & \multirow[t]{2}{*}{21} \\
\hline & & Private & 4 & 4 & \\
\hline \multirow[t]{2}{*}{5} & Effutu Municipal & Public & 4 & 3 & \multirow[t]{2}{*}{14} \\
\hline & & Private & 5 & 2 & \\
\hline \multirow[t]{2}{*}{6} & Agona East & Public & 9 & 9 & \multirow[t]{2}{*}{26} \\
\hline & & Private & 5 & 3 & \\
\hline Tota & & & 62 & 64 & 126 \\
\hline
\end{tabular}


To determine the sample size in terms of schools for the study, I used proportionate stratified random sampling to ensure that the proportion of each stratification variable (private urban, private rural, public urban and public rural) in the sample reflects their proportion in the wider population. To determine the number of schools in the study, $30 \%$ of the total number of schools of 420 was taken which was 126 to make up the sample.

Table 2 depicts the final distribution for the study sample size by school type and location from which data were gathered. From Table 2, 62 of the schools were in the urban centres, while, 64 were from rural centres. Respondents for the study were made up of 126 head teachers, 378 JHS three (3) teachers (thus, those who were teaching English language, mathematics and science) and 756 JHS 3 students, six (6) students were randomly selected per school. In all, the participants for the study were 1260.

The data collected with the questionnaires were coded and inputted using the SPSS software version 25.0. The responses to all the items on the questionnaire were numerically coded. The inputted data were then cleaned to identify errors and miskeyed responses. Data gathered were answered using frequencies, percentages, means and standard deviations.

\section{RESULTS}

The study collected data from 1260 participants in three sub-sample groups: teachers, headteachers and pupils. On the part of teachers, 325 out of 378 JHS teachers participated with a response rate of $86 \%$. One hundred and eleven (111) representing $88.1 \%$ out of the 126 head teachers participated. In terms of students, 674 out of 756 participated, and this represents a return rate of $89.2 \%$. The overall return rate is $88.1 \%$. This chapter presents the results of the data collected from the field and discusses the results.

To achieve the purpose of the study, respondents were asked to indicate the (a) availability and (b) quality of some materials and facilities, and their responses are presented in Tables 3, 4 and 5. Table 3 shows the current status of the class size in rural, urban, private and public schools.

Table-3. Class Size (Headteachers).

\begin{tabular}{|c|c|c|c|c|c|c|c|c|c|c|}
\hline \multirow[b]{3}{*}{ Range } & \multicolumn{2}{|c|}{ All } & \multicolumn{4}{|c|}{ Location } & \multicolumn{4}{|c|}{ School Type } \\
\hline & \multirow[b]{2}{*}{$\mathbf{F}$} & \multirow[b]{2}{*}{$\%$} & \multicolumn{2}{|c|}{ Rural } & \multicolumn{2}{|c|}{ Urban } & \multicolumn{2}{|c|}{ Private } & \multicolumn{2}{|c|}{ Public } \\
\hline & & & $\mathbf{F}$ & $\%$ & $\mathbf{F}$ & $\%$ & $\mathbf{F}$ & $\%$ & $\mathbf{F}$ & $\%$ \\
\hline $1-35$ & 88 & 79.3 & 57 & 90.5 & 31 & 64.6 & 22 & 81.5 & 66 & 78.6 \\
\hline $36-70$ & 20 & 18.0 & 6 & 9.5 & 14 & 29.2 & 5 & 18.5 & 15 & 17.9 \\
\hline $71-105$ & 1 & 0.9 & - & - & 1 & 2.1 & - & - & 1 & 1.2 \\
\hline $\mathrm{N} / \mathrm{A}$ & 2 & 1.8 & - & - & 2 & 4.2 & - & - & 2 & 2.4 \\
\hline Total & 111 & 100.0 & 63 & 100.0 & 48 & 100.0 & 27 & 100.0 & 84 & 100.0 \\
\hline
\end{tabular}

Note: N/A - No response.

$\mathrm{F}=$ Frequency, $\%=$ Percentage.

From Table 3, 90.5\% and $64.6 \%$ of the schools in the rural and urban settings respectively had class sizes ranging from 1 to 35 . While $9.5 \%$ of schools in rural settings had class sizes ranging from 36 to $70,29.2 \%$ of schools in urban settings had class sizes ranging from 36 to 70 . In terms of school type, $81.5 \%$ of private and $78.6 \%$ of public schools had class sizes ranging from 1 to 35 . A greater portion (18.5\%) of private schools than public schools (17.9) had class sizes ranging from 36 to 70. Generally, it can be said that urban schools had class sizes larger than the recommended class size by GES, Ghana. In a similar vein, public schools had larger class sizes than private schools.

Table 4 presents results on the availability of textbooks. Regarding the availability of English textbooks, less than half of the students 243 (36.1\%) reported that two people shared one English textbook, 214 (31.8\%) had one English textbook for themselves, $114(16.9 \%)$ of the students indicated that three people shared one English 
textbook, 62 (9.2\%) reported that five or more people shared one English textbook while only 33 (4.9\%) of the students reported that four people shared one English textbook (see Table 4). This suggests that there were not enough English textbooks for all the students in their respective classes. Concerning the availability of Mathematics textbooks, the results showed that less than half of the students 272 (40.4\%) had one Mathematics next book each for themselves, $182(27.0 \%)$ of the students reported that two people shared one Mathematics textbook.

Table-4.Availability of Textbooks (Pupils)

\begin{tabular}{|c|c|c|c|c|c|c|c|c|c|c|}
\hline \multirow{3}{*}{$\begin{array}{l}\text { Books } \\
\text { English Language }\end{array}$} & \multirow{2}{*}{\multicolumn{2}{|c|}{ All }} & \multicolumn{4}{|c|}{ Location } & \multicolumn{4}{|c|}{ School Type } \\
\hline & & & \multicolumn{2}{|c|}{ Rural } & \multicolumn{2}{|c|}{ Urban } & \multicolumn{2}{|c|}{ Private } & \multicolumn{2}{|c|}{ Public } \\
\hline & $\mathrm{F}$ & $\%$ & $\mathrm{~F}$ & $\%$ & $\mathrm{~F}$ & $\%$ & $\mathrm{~F}$ & $\%$ & $\mathrm{~F}$ & $\%$ \\
\hline I have one book for myself & 214 & 31.8 & 72 & 21.4 & 142 & 42.1 & 122 & 68.9 & 92 & 18.5 \\
\hline Two people share one book & 243 & 36.1 & 143 & 42.4 & 100 & 29.7 & 41 & 23.2 & 202 & 40.6 \\
\hline Three people share one book & 114 & 16.9 & 55 & 16.3 & 59 & 17.5 & 6 & 3.4 & 108 & 21.7 \\
\hline Four people share one book & 33 & 4.9 & 21 & 6.2 & 12 & 3.6 & 3 & 1.7 & 30 & 6.0 \\
\hline $\begin{array}{l}\text { Five or more people share } \\
\text { one book }\end{array}$ & 62 & 9.2 & 38 & 11.3 & 24 & 7.1 & 3 & 1.7 & 59 & 11.9 \\
\hline $\mathrm{N} / \mathrm{A}$ & 8 & 1.2 & 8 & 2.4 & & & 2 & 1.1 & 6 & 1.2 \\
\hline \multicolumn{11}{|l|}{ Mathematics } \\
\hline I have one book for myself & 272 & 40.4 & 115 & 34.1 & 157 & 46.6 & 136 & 76.8 & 136 & 27.4 \\
\hline Two people share one book & 182 & 27.0 & 111 & 32.9 & 71 & 21.1 & 23 & 13.0 & 159 & 32.0 \\
\hline Three people share one book & 44 & 6.5 & 30 & 8.9 & 14 & 4.2 & 6 & 3.4 & 38 & 7.6 \\
\hline Four people share one book & 19 & 2.8 & 12 & 3.6 & 7 & 2.1 & 1 & .6 & 18 & 3.6 \\
\hline $\begin{array}{l}\text { Five or more people share } \\
\text { one book }\end{array}$ & 140 & 20.8 & 61 & 18.1 & 79 & 23.4 & 6 & 3.4 & 134 & 27.0 \\
\hline $\mathrm{N} / \mathrm{A}$ & 17 & 2.5 & 8 & 2.4 & 9 & 2.7 & 5 & 2.8 & 12 & 2.4 \\
\hline \multicolumn{11}{|l|}{ Integrated Science } \\
\hline I have one book for myself & 274 & 40.7 & 108 & 32.0 & 166 & 49.3 & 145 & 81.9 & 129 & 26.0 \\
\hline Two people share one book & 148 & 22.0 & 99 & 29.4 & 49 & 14.5 & 19 & 10.7 & 129 & 26.0 \\
\hline Three people share one book & 60 & 8.9 & 36 & 10.7 & 24 & 7.1 & 3 & 1.7 & 57 & 11.5 \\
\hline Four people share one book & 28 & 4.2 & 16 & 4.7 & 12 & 3.6 & 3 & 1.7 & 25 & 5.0 \\
\hline $\begin{array}{l}\text { Five or more people share } \\
\text { one book }\end{array}$ & 146 & 21.7 & 69 & 20.5 & 77 & 22.8 & 4 & 2.3 & 142 & 28.6 \\
\hline $\mathrm{N} / \mathrm{A}$ & 18 & 2.7 & 9 & 2.7 & 9 & 2.7 & 3 & 1.7 & 15 & 3.0 \\
\hline
\end{tabular}

In addition, $140(20.8 \%)$ of the students indicated that five or more people shared one Mathematics textbook, 44 $(6.5 \%)$ of the students reported that three people shared one mathematics textbook. This implies that there were not enough mathematics textbooks for all the students in their respective schools. The data further revealed that less than half of the students $274(40.7 \%)$ had one integrated science textbook for themselves, $148(22.0 \%)$ of the students indicated that two people shared one integrated science textbook, 146 (21.7\%) of the students reported that five or more people shared one integrated science textbook, $60(8.9 \%)$ of the students reported that three people shared one integrated textbook, while only $28(4.2 \%)$ of the students indicated that four people shared one integrated science textbook.

Reports from the students' perspective regarding the availability of English, Mathematics and Integrated Science textbooks indicated that although all the students did not get individual textbooks for the aforementioned subjects, some of the students had the opportunity to share a single textbook with their friends. This could affect the academic performance of students to some extent since such materials are needed to enhance teaching and learning in the classroom. Based on the findings of this study, it can be said that the quality of education at the JHS level in the Central Region of Ghana is not at the ultimate level expected. 
Regarding the availability of English textbooks, 21.4\% of students in the rural schools reported that one student had one English textbook for himself/herself, $11.3 \%$ of students in the rural schools reported that five or more students shared one English textbook. In the case of the urban schools, $42.1 \%$ of students reported that each student had an English textbook for himself/herself, 7.1\% of the students indicated five or more students shared English textbooks in the urban schools. It could be inferred from the results that students in urban schools had greater access to English textbooks compared to students in rural schools. The results in Table 4 shows that $68.9 \%$ of students in private schools had one English textbook each for themselves, $1.7 \%$ of the students in the private school reported that five or more people shared one English textbook. In the case of public schools, $18.5 \%$ of the students reported that each student had one English textbook for himself/herself, $11.9 \%$ of the students indicated that five or more students shared one textbook in the public schools. This suggests that the availability of English textbooks in private schools outweighs the English textbooks in public schools.

Concerning the availability of mathematics textbooks, $34.1 \%$ of students in the rural schools had one mathematics textbook for themselves, $18.1 \%$ of students in the rural schools shared one mathematics textbook among five or more people. In the case of urban schools, the results in Table 4 shows that $46.6 \%$ of students in urban schools had one mathematics textbook for themselves, 23.4\% of students in urban schools shared one mathematics book among five or more pupils. This implies that students in urban schools have adequate access to a mathematics textbook compared to students in rural schools. With reference to school types, $76.8 \%$ of students in private schools had one mathematics textbook for themselves while $3.4 \%$ of students in private schools shared one mathematics textbook among five students. Results in Table 5 further shows that $27.4 \%$ of students in public schools had one mathematics textbook for themselves whereas $27.0 \%$ of students in public schools shared one mathematics textbook among five or more students. This implies that students in private schools had sufficient access to mathematics textbooks compared to their counterparts in public schools.

Table-5. Responses from Headteachers on Availability of Textbooks- $(n=111)$.

\begin{tabular}{|c|c|c|c|c|c|c|c|c|c|c|}
\hline \multirow{3}{*}{$\begin{array}{l}\text { Books } \\
\text { English }\end{array}$} & \multicolumn{2}{|c|}{ All } & \multicolumn{4}{|c|}{ Location } & \multicolumn{4}{|c|}{ Sch. Type } \\
\hline & & & \multicolumn{2}{|c|}{ Rural } & \multicolumn{2}{|c|}{ Urban } & \multicolumn{2}{|c|}{ Private } & \multicolumn{2}{|c|}{ Public } \\
\hline & $\mathrm{F}$ & $\%$ & $\mathrm{~F}$ & $\%$ & $\mathrm{~F}$ & $\%$ & $\mathrm{~F}$ & $\%$ & $\mathrm{~F}$ & $\%$ \\
\hline $1: 1$ & 22 & 19.8 & 11 & 17.5 & 11 & 22.9 & 13 & 48.1 & 9 & 10.7 \\
\hline $1: 2$ & 34 & 30.6 & 20 & 31.7 & 14 & 29.2 & 7 & 25.9 & 27 & 32.1 \\
\hline $1: 3$ & 27 & 24.3 & 14 & 22.2 & 13 & 27.1 & 6 & 22.2 & 21 & 25.0 \\
\hline $1: 4$ & 7 & 6.3 & 5 & 7.9 & 2 & 4.2 & 1 & 3.7 & 6 & 7.1 \\
\hline $1: 5$ & 18 & 16.2 & 12 & 19.0 & 6 & 12.5 & - & - & 18 & 21.4 \\
\hline $\mathrm{N} / \mathrm{A}$ & 3 & 2.7 & 1 & 1.6 & 2 & 4.2 & - & - & 3 & 3.6 \\
\hline Total & 111 & 100.0 & 63 & 100.0 & 48 & 100.0 & 27 & 100.0 & 84 & 100.0 \\
\hline \multicolumn{11}{|c|}{ Mathematics } \\
\hline $1: 1$ & 23 & 20.7 & 12 & 19.0 & 11 & 22.9 & 13 & 48.1 & 10 & 11.9 \\
\hline $1: 2$ & 40 & 36.0 & 26 & 41.3 & 14 & 29.2 & 9 & 33.3 & 31 & 36.9 \\
\hline $1: 3$ & 16 & 14.4 & 9 & 14.3 & 7 & 14.6 & 3 & 11.1 & 13 & 15.5 \\
\hline $1: 4$ & 7 & 6.3 & 4 & 6.3 & 3 & 6.3 & 2 & 7.4 & 5 & 6.0 \\
\hline $1: 5$ & 22 & 19.8 & 11 & 17.5 & 11 & 22.9 & - & - & 22 & 26.2 \\
\hline $\mathrm{N} / \mathrm{A}$ & 3 & 2.7 & 1 & 1.6 & $\mathcal{Q}$ & 4.2 & - & - & 3 & 3.6 \\
\hline Total & 111 & 100.0 & 63 & 100.0 & 48 & 100.0 & 27 & 100.0 & 84 & 100.0 \\
\hline Science & $\mathrm{F}$ & $\%$ & $\mathrm{~F}$ & $\%$ & $\mathrm{~F}$ & $\%$ & $\mathrm{~F}$ & $\%$ & $\mathrm{~F}$ & $\%$ \\
\hline $1: 1$ & 18 & 16.2 & 8 & 12.7 & 10 & 20.8 & 11 & 40.7 & 7 & 8.3 \\
\hline $1: 2$ & 32 & 28.8 & 18 & 28.6 & 14 & 29.2 & 8 & 29.6 & 24 & 28.6 \\
\hline $1: 3$ & 26 & 23.4 & 17 & 27.0 & 9 & 18.8 & 5 & 18.5 & 21 & 25.0 \\
\hline $1: 4$ & 8 & 7.2 & 5 & 7.9 & 3 & 6.3 & 2 & 7.4 & 6 & 7.1 \\
\hline $1: 5$ & 25 & 22.5 & 14 & 22.2 & 11 & 22.9 & 1 & 3.7 & 24 & 28.6 \\
\hline $\mathrm{N} / \mathrm{A}$ & 2 & 1.8 & 1 & 1.6 & 1 & 2.1 & - & - & - & - \\
\hline Total & 111 & 100.0 & 63 & 100.0 & 48 & 100.0 & 27 & 100.0 & 84 & 100.0 \\
\hline
\end{tabular}


Concerning the availability of science textbooks, $32 \%$ of students in the rural schools reported that they had one science textbook each for themselves, $20.5 \%$ of students in the rural schools indicated that students shared one science textbook with five or more people. In the case of urban schools, however, $49.3 \%$ of students in the urban schools indicated they had one science textbook each for themselves, $22.8 \%$ of the urban school students indicated that one science textbook was shared by five or more students. This is a clear indication that students in urban schools had sufficient access to integrated science textbooks compared to their counterparts in rural schools. Similarly, $81.9 \%$ of students in private schools had one science textbook each for themselves, $2.3 \%$ of the students in the private schools reported that they shared one science textbook with five or more students. In the case of the public schools, $26 \%$ of students in public schools had one science textbook each for themselves, 28.6 of students in the public school shared one science textbook among five or more students. This indicates the inadequacy of science textbooks in public schools compared to private schools. From Table 5, 17.5\% of headteachers in the rural schools reported an English textbook ratio of one book to one student (1:1), 19.0\% of the headteachers reported an English textbook ratio of one book to five students (1:5). In the case of the urban schools, $22.9 \%$ of the headteachers in the urban schools reported an English textbook ratio of one book to one student (1:1) while 12.5\% reported an English textbook ratio of one book to five students (1:5). The headteachers' report with reference to school location indicates that there are more English textbooks in the urban schools compared to the rural schools. Concerning the school types, $48.1 \%$ of the headteachers in the private schools reported an English textbook ratio of one book to one student (1:1). In the case of public schools, $10.7 \%$ of the headteachers reported an English textbook ratio of one book to one student (1), 21.4\% of the headteachers reported a textbook ratio of one book to five students (1:5). This is suggesting that there were more English textbooks in private schools compared to public schools. Concerning the availability of Mathematics textbooks, $19 \%$ of headteachers in rural schools reported a textbook ratio of one book to one person, $17.5 \%$ reported a ratio of one book to five students. In the case of urban schools, $22.9 \%$ of headteachers in the urban schools reported a textbook ratio of one book to one person, $22.9 \%$ also reported a ratio of one book to five students. Concerning the school types, $48.1 \%$ of headteachers in the private schools reported a textbook ratio of one book to one student, none of the headteachers reported on the textbook ratio of one book to five students. In the case of the public schools, $11.9 \%$ of the headteachers in the public schools reported a textbook ratio of one book to one student while $26.2 \%$ reported a textbook ratio of one book to five students. The results show that there were enough mathematics textbooks in urban schools compared to rural schools. In the same vein, there was enough mathematics textbook in private schools compared to public schools. Regarding the availability of Science textbooks, $12.7 \%$ of headteachers in the rural schools reported a textbook ratio of one book to one student, $22.2 \%$ reported a ratio of one book to five students. In the case of urban schools, $20.8 \%$ of headteachers in the urban schools reported a textbook ratio of one book to one person, $22.9 \%$ reported a ratio of one book to five students. Regarding the school types, $40.7 \%$ of the headteachers in the private schools reported a textbook ratio of one book to one student, $3.7 \%$ of the headteachers reported on a textbook ratio of one book to five students. In the case of the public schools, however, $8.3 \%$ of the headteachers in the public schools reported a textbook ratio of one book to one student while $28.6 \%$ reported a textbook ratio of one book to five students. This presents a piece of clear evidence that the Science textbooks at the urban schools were more than the textbooks at the rural schools. Similarly, the Science textbooks at the private schools were more than those at the public schools.

\subsection{Other Input Factors}

Aside the availability of textbooks, other inputs were considered. Respondents were asked to indicate the availability of other input factors such as access to a library, table and chairs, electricity, science laboratory among 
others. The inputs were measured using a semantic differential scale that ranged from 1-5; where $1=$ "no extent" and 5 ="greater extent." No extent depicts a situation where the input factor is non-existent and greater extent depicts a situation where the input factor exists, is adequate and is of high quality. Mean scores were computed. Mean scores of 3 depict a situation where the input factor is fairly efficient and adequate. A mean score greater than 3 depicts a situation where the input factor exists, adequate and is of high quality. A mean score of less than 3 depicts otherwise. The responses are presented in Tables 6-7.

As shown in Table 6, most of the students reported that spaces within the classroom allow free movement during lesson delivery $(M=4.11, S D=1.21)$, most of the students also reported that they had access to a table and chair/desk/mono desk in the classroom $(M=3.97, S D=1.35)$, the students further reported that their parents provided the needed material such as books, pencils and pens for their learning at school $(M=3.81, S D=1.32)$. The results in Table 6 further revealed that some of the students reported there was non-availability and accessibility to some other books such as storybooks in the school $(M=2.69, S D=1.58)$, while others reported that they did not have access to the library in the school $(M=2.18, S D=1.61)$. Students further reported that the science lab was not equipped with materials and equipment $(M=1.34, S D=0.94)$. They also reported that the schools had no science laboratory. $(M=1.23, S D=0.79)$.

Table-6. Other Inputs Available (Pupils)

\begin{tabular}{|c|c|c|c|c|c|c|c|c|c|c|}
\hline \multirow[t]{3}{*}{ Factors } & \multicolumn{2}{|c|}{ All } & \multicolumn{4}{|c|}{ Location } & \multicolumn{4}{|c|}{ School Type } \\
\hline & \multirow[b]{2}{*}{$M$} & \multirow[b]{2}{*}{$S D$} & \multicolumn{2}{|c|}{ Rural } & \multicolumn{2}{|c|}{ Urban } & \multicolumn{2}{|c|}{ Private } & \multicolumn{2}{|c|}{ Public } \\
\hline & & & $M$ & $S D$ & $M$ & $S D$ & $M$ & $S D$ & $M$ & $S D$ \\
\hline $\begin{array}{l}\text { There are some other } \\
\text { books such as storybooks } \\
\text { in the school for students } \\
\text { to access. }\end{array}$ & 2.69 & 1.58 & 2.43 & 1.45 & 2.96 & 1.64 & 2.94 & 1.56 & 2.61 & 1.58 \\
\hline $\begin{array}{l}\text { I have access to a library } \\
\text { in the school/classroom }\end{array}$ & 2.18 & 1.61 & 1.78 & 1.40 & 2.57 & 1.70 & 2.48 & 1.60 & 2.07 & 1.60 \\
\hline $\begin{array}{l}\text { I have access to a table } \\
\text { and chair/desk/mono } \\
\text { desk in the classroom. }\end{array}$ & 3.97 & 1.35 & 3.83 & 1.309 & 4.11 & 1.37 & 4.06 & 1.35 & 3.94 & 1.35 \\
\hline $\begin{array}{l}\text { The school has access to } \\
\text { electricity. }\end{array}$ & 3.56 & 1.611 & 3.18 & 1.65 & 3.94 & 1.48 & 3.80 & 1.50 & 3.48 & 1.64 \\
\hline $\begin{array}{l}\text { The school has a science } \\
\text { laboratory. }\end{array}$ & 1.23 & 0.79 & 1.16 & 0.71 & 1.30 & 0.85 & 1.49 & 1.13 & 1.12 & 0.60 \\
\hline $\begin{array}{l}\text { The science laboratory is } \\
\text { equipped with materials } \\
\text { and equipment. }\end{array}$ & 1.34 & 0.94 & 1.30 & 0.93 & 1.37 & 0.96 & 1.50 & 1.01 & 1.28 & 0.906 \\
\hline $\begin{array}{l}\text { Spaces within the } \\
\text { classrooms allow free } \\
\text { movement during lesson } \\
\text { delivery. }\end{array}$ & 4.11 & 1.21 & 4.11 & 1.17 & 4.13 & 1.25 & 4.0 & 1.21 & 4.17 & 1.20 \\
\hline $\begin{array}{l}\text { My parents provide the } \\
\text { needed material (books, } \\
\text { pencils, pens for, etc) for } \\
\text { my learning at school }\end{array}$ & 3.81 & 1.32 & 3.56 & 1.31 & 4.05 & 1.28 & 4.07 & 1.13 & 3.71 & 1.37 \\
\hline $\begin{array}{l}\text { My parents often visit } \\
\text { the school to appraise my } \\
\text { academic achievement } \\
\text { level with the teacher }\end{array}$ & 2.5 & 1.47 & 2.15 & 1.32 & 2.85 & 1.52 & 2.93 & 1.45 & 2.35 & 1.44 \\
\hline
\end{tabular}

As presented in Table 6, students indicated that there were more spaces within the classrooms of schools in the urban settings $(M=4.13, S D=1.25)$ as compared to schools in the rural settings $(M=4.11, S D=1.17)$. Thus, there was free movement during lessons in urban setting schools compared to rural setting schools. In terms of 
school types, students reported that parents who had their wards in private schools provided the needed materials for their children learning $(M=4.07, S D=1.13)$ compared to parents who had their wards in the public schools $(M$ $=3.17, S D=1.37)$. As shown in Table 7 , most teachers indicated that students had access to a table and a chair/dual or dual/mono desk in the classroom $(M=3.89, S D=1.25)$, while others reported that spaces within the classrooms allowed for free movement during lesson delivery $(M=3.85, S D=1.12)$. Teachers further reported that they used teaching and learning materials to illustrate concepts in their classrooms $(M=3.58, S D=1.03)$. They also indicated that their schools had regular access to electricity $(M=3.48, S D=1.66)$. Inferring from the reports of students on the availability of other input factors, one can conclude that on average most of the other inputs were available to some extent. For instance, it was observed from the report of the students that spaces within the classroom allow free movement during lesson delivery. This input, for instance, was in high existence and adequate.

Table-7. Other inputs available (Teachers).

\begin{tabular}{|c|c|c|c|c|c|c|c|c|c|c|}
\hline \multirow[t]{3}{*}{ Factors } & \multirow{2}{*}{\multicolumn{2}{|c|}{ ALL }} & \multicolumn{4}{|c|}{ Location } & \multicolumn{4}{|c|}{ Sch. Type } \\
\hline & & & \multicolumn{2}{|c|}{ Rural } & \multicolumn{2}{|c|}{ Urban } & \multicolumn{2}{|c|}{ Private } & \multicolumn{2}{|c|}{ Public } \\
\hline & $\mathbf{M}$ & SD & $\mathbf{M}$ & SD & $\mathbf{M}$ & SD & $\mathbf{M}$ & SD & M & SD \\
\hline $\begin{array}{l}\text { There are supplementary } \\
\text { books in my subject area } \\
\text { for students to access. }\end{array}$ & 2.21 & 1.34 & 1.97 & 1.18 & 2.45 & 1.46 & 2.60 & 1.50 & 2.04 & 1.24 \\
\hline $\begin{array}{l}\text { Students have access to } \\
\text { the library in the } \\
\text { school/classroom. }\end{array}$ & 2.02 & 1.33 & 1.71 & 1.20 & 2.35 & 1.40 & 2.72 & 1.48 & 1.74 & 1.16 \\
\hline $\begin{array}{l}\text { I use teaching-learning } \\
\text { materials to illustrate } \\
\text { concepts in my } \\
\text { classroom(s). }\end{array}$ & 3.58 & 1.03 & 3.40 & 1.11 & 3.77 & 0.908 & 3.60 & 1.05 & 3.57 & 1.02 \\
\hline $\begin{array}{l}\text { There are instructional } \\
\text { materials for teaching and } \\
\text { learning in my subject } \\
\text { area. }\end{array}$ & 3.24 & 1.23 & 3.08 & 1.25 & 3.40 & 1.18 & 3.57 & 1.28 & 3.10 & 1.18 \\
\hline $\begin{array}{l}\text { Students have access to a } \\
\text { table and chair/dual, } \\
\text { dual/mono desk in the } \\
\text { classroom. }\end{array}$ & 3.89 & 1.25 & 3.88 & 1.24 & 3.90 & 1.26 & 4.08 & 1.40 & 3.82 & 1.17 \\
\hline $\begin{array}{l}\text { The school has access to } \\
\text { electricity. }\end{array}$ & 3.48 & 1.66 & 3.21 & 1.66 & 3.76 & 1.60 & 3.70 & 1.69 & 3.39 & 1.64 \\
\hline $\begin{array}{l}\text { The school has a science } \\
\text { laboratory. }\end{array}$ & 1.35 & 0.88 & 1.30 & 0.82 & 1.40 & 0.95 & 1.55 & 1.07 & 1.27 & 0.78 \\
\hline $\begin{array}{l}\text { The science laboratory is } \\
\text { equipped with materials } \\
\text { and equipment. }\end{array}$ & 1.54 & 1.13 & 1.41 & 0.99 & 1.68 & 1.25 & 1.90 & 1.34 & 1.39 & 1.00 \\
\hline $\begin{array}{l}\text { Spaces within the } \\
\text { classrooms allow free } \\
\text { movement during lesson } \\
\text { delivery. }\end{array}$ & 3.85 & 1.12 & 3.82 & 1.18 & 3.88 & 1.06 & 3.91 & 1.16 & 3.83 & 1.11 \\
\hline $\begin{array}{l}\text { Parents provide the } \\
\text { needed material (books, } \\
\text { pens, pencils, etc.) for } \\
\text { their children learning at } \\
\text { school. }\end{array}$ & 3.04 & 1.27 & 2.93 & 1.16 & 3.15 & 1.37 & 3.73 & 1.33 & 2.75 & 1.13 \\
\hline $\begin{array}{l}\text { Parents visit the school to } \\
\text { appraise the achievement } \\
\text { level of their children at } \\
\text { least two times in a term. }\end{array}$ & 2.25 & 1.28 & 2.10 & 1.20 & 2.41 & 1.35 & 3.01 & 1.43 & 1.94 & 1.08 \\
\hline
\end{tabular}


It was further evident in Table 7 that teachers indicated that instructional materials for teaching and learning in the subject area of Mathematics, English and Science were inadequate numbers $(M=3.24, S D=1.23)$. They, however, reported that parents failed to provide the needed materials such as books, pens and pencils for their children learning at school. The teachers also indicated that parents did not visit the school to appraise the achievement level of their children at least two times in term $(M=2.25 S D=1.28)$. They further reported that there were inadequate supplementary books in their subject areas for students to access $(M=2.21, S D=1.34)$ and that students did not have access to the library in the school/classroom $(M=2.02, S D=1.33)$. The teachers also reported that the science laboratory was not equipped with materials and equipment $(M=1.54, S D=1.13)$, and thus, their schools did not have a science laboratory $(M=1.35, S D=0.88)$.

Table-8. Other Input Available (Head-teachers) $(\mathrm{n}=111)$.

\begin{tabular}{|c|c|c|c|c|c|c|c|c|c|c|}
\hline \multirow[t]{3}{*}{ Factors } & \multirow{2}{*}{\multicolumn{2}{|c|}{ ALL }} & \multicolumn{4}{|c|}{ Location } & \multicolumn{4}{|c|}{ School Type } \\
\hline & & & \multicolumn{2}{|c|}{ Rural } & \multicolumn{2}{|c|}{ Urban } & \multicolumn{2}{|c|}{ Private } & \multicolumn{2}{|c|}{ Public } \\
\hline & $M$ & $S D$ & $M$ & $S D$ & $M$ & $S D$ & $M$ & $S D$ & $M$ & $S D$ \\
\hline $\begin{array}{l}\text { There are supplementary } \\
\text { books in my subject area for } \\
\text { students to access. }\end{array}$ & 2.63 & 1.20 & 2.59 & 1.23 & 2.68 & 1.16 & 3.00 & 1.33 & 2.51 & 1.13 \\
\hline $\begin{array}{l}\text { I students have access to } \\
\text { the library in the } \\
\text { school/classroom. }\end{array}$ & 1.99 & 1.30 & 1.87 & 1.34 & 2.15 & 1.25 & 2.63 & 1.57 & 1.78 & 1.14 \\
\hline $\begin{array}{lrr}\text { I use teaching-learning } \\
\text { materials to } \\
\text { concepts illustrate } \\
\text { classroom(s). }\end{array}$ & 2.14 & 1.33 & 2.10 & 1.42 & 2.19 & 1.21 & 2.56 & 1.48 & 2.00 & 1.26 \\
\hline $\begin{array}{l}\text { There are instructional } \\
\text { materials for the teaching } \\
\text { and learning process in my } \\
\text { subject area. }\end{array}$ & 3.43 & 0.96 & 3.43 & 1.01 & 3.43 & 0.903 & 3.74 & 0.94 & 3.32 & 0.95 \\
\hline $\begin{array}{l}\text { Students have access to a } \\
\text { table and chair/dual, } \\
\text { dual/mono desk in the } \\
\text { classroom. }\end{array}$ & 3.68 & 1.39 & 3.68 & 1.34 & 3.68 & 1.46 & 4.00 & 1.52 & 3.58 & 1.34 \\
\hline $\begin{array}{l}\text { The school has access to } \\
\text { electricity. }\end{array}$ & 3.37 & 1.71 & 3.16 & 1.71 & 3.66 & 1.70 & 3.56 & 1.78 & 3.3133 & 1.70 \\
\hline $\begin{array}{l}\text { The school has a science } \\
\text { laboratory. }\end{array}$ & 1.25 & 0.76 & 1.13 & 0.46 & 1.43 & 1.02 & 1.37 & 1.01 & 1.22 & 0.66 \\
\hline $\begin{array}{l}\text { The science laboratory is } \\
\text { equipped with materials } \\
\text { and equipment. }\end{array}$ & 1.42 & 1.02 & 1.59 & 1.17 & 1.20 & 0.72 & 1.42 & 0.90 & 1.42 & 1.07 \\
\hline $\begin{array}{llr}\text { Spaces } & \text { within } & \text { the } \\
\text { classrooms } & \text { allow } & \text { free } \\
\text { movement } & \text { during } & \text { lesson } \\
\text { delivery. } & & \end{array}$ & 3.77 & 1.27 & 3.6508 & 1.25 & 3.94 & 1.29 & 3.63 & 1.40 & 3.82 & 1.23 \\
\hline $\begin{array}{l}\text { Parents provide the needed } \\
\text { material (books, pens, } \\
\text { pencils, etc.) for their } \\
\text { children learning at school. }\end{array}$ & 3.28 & 1.14 & 3.18 & 1.03 & 3.40 & 1.26 & 3.81 & 1.04 & 3.10 & 1.12 \\
\hline $\begin{array}{l}\text { Parents visit the school to } \\
\text { appraise the achievement } \\
\text { level of their children at } \\
\text { least two times in the term. }\end{array}$ & 2.49 & 1.22 & 2.48 & 1.19 & 2.51 & 1.27 & 3.15 & 1.29 & 2.28 & 1.12 \\
\hline
\end{tabular}

As presented in Table 7, teachers indicated that students in the urban settings had enough access to a table and chair/dual, dual/mono desk in the classroom $(M=3.90, S D=1.26)$ as compared to students in the rural settings $(M=3.88, S D=1.24)$. Similarly, in terms of school types, teachers reported that students in the private schools had enough access to a table and chair/dual, dual/mono desk in the classroom $(M=4.08, S D=1.40)$ compared to their counterparts in the public schools $(M=3.82, S D=1.17)$. Table 8 indicated that most of the headteachers reported that spaces within the classrooms allowed free movement during lesson delivery $(M=3.77, S D=1.27)$ and that 
students had access to a table and chair/dual or dual/mono desk in the classroom $(M=3.68, S D=1.39)$. The headteachers also reported that there were instructional materials for teaching and learning in their various subject areas $(M=3.43, S D=0.96)$, while others revealed that their school had access to electricity $(M=3.37, S D=1.71)$. It is further revealed in Table 8 per the reports of headteachers that parents provided the needed material such as books, pens and pencils for their children's learning at school $(M=3.28, S D=1.14)$. The headteachers also indicated that there were no supplementary textbooks for their respective subject areas for students to use $(M=$ 2.63, $S D=1.20$ ). It was also clear in the responses of headteachers that parents did not visit the school to appraise the achievement level of their children at least two times in a term $(M=2.49, S D=1.22)$. The headteachers further reported that students did not have access to the library in the school/classroom $(M=1.99, S D=1.30)$, and also the science laboratories were not equipped with materials and equipment $(M=1.42, S D=1.02)$. As presented in Table 8, headteachers indicated that students in the urban settings had equal access to a table and chair/dual, $\mathrm{dual} /$ mono desk in the classroom $(M=3.68, S D=1.34)$ as their counterparts in the rural settings $(M=3.68, S D=$ 1.46). In terms of school types, the headteachers reported that students in the private schools had enough access to a table and chair/dual, dual/mono desk in the classroom $(M=4.00, S D=1.52)$ compared to students in the public schools $(M=3.58, S D=1.34)$. In sum, it appears from the results of the current study that textbook pupil ratio was better in urban schools and private schools as well for English, Mathematics and Integrated Science. In addition, other input factors were present in urban schools to a greater extent; these factors were poor for rural schools for the teaching of core subjects. Private schools reported the availability of other process factors than public schools. Regarding schools' class size, it can be said that urban schools had class sizes larger than the recommended class size by GES, Ghana. In a similar vein, private schools had larger class sizes than public schools.

\subsection{Highlights of Key Findings}

It was found that urban schools had class sizes larger than the recommended class size by GES, Ghana. Public schools had larger class sizes than private schools. Also, the textbook pupil ratio was better in urban schools and private schools as well for English, Mathematics and Integrated Science. In addition, other input factors were present in urban schools to a greater extent; these factors were poor for rural schools for the teaching of core subjects. Regarding the availability of English textbooks, the students reported that two people shared one English textbook. The students had one Mathematics as well as Integrated Science textbook each for themselves. On the issue of the English textbook-student ratio, the teachers reported a ratio of one book to one student. In the same vein, the headteachers reported a ratio of one textbook to two pupils. The teachers reported a ratio of one book to five or more pupils for Mathematics and Integrated Science. The headteachers reported a ratio of one Mathematics textbook to two students. The teachers reported a ratio of one Integrated Science textbook to five or more students.

From the pupils' perspective, parents provided needed materials, their schools had electricity access, and parents often visited the school to appraise their academic level with their teachers. However, availability and access to some other books, tables and chairs, science laboratory resources were not present. The teachers were of the view that: parents did not visit the school to appraise their children's performance; supplementary materials were not accessible; the library was also not accessible; and non-availability of materials in a science laboratory. Both teachers and headteachers reported that: there were spaces within the classrooms that allowed free movement during lessons; students had access to tables and chairs; instructional materials were available; the school had access to electricity, and parents provided needed materials for their children. Just like the teachers, the headteachers also reiterated that: parents did not visit the school to appraise the achievement of their wards regularly; library facilities were non-existent, and science laboratory materials were not available. Generally, it was discovered that the input 
factors in urban areas were better than those in rural areas. Even in cases where the inputs factors were present in both rural and urban school, the rate of accessibility or availability in urban schools were better in rural schools. Similarly, private schools were found to have better input factors as compared to public schools.

\section{DISCUSSION}

The results of the current study show that urban schools had class sizes larger than the recommended class size by GES, Ghana. In a similar vein, private schools had larger class sizes than public schools. This result has implications for teachers' responsibility in the classroom, in that, a teacher who has a large class size may find it difficult controlling and managing the behaviours of students in the classroom. Large class size could also pose a severe challenge to the teacher in that, the teacher may not be able to attend to the academic as well as the social needs of every student in the classroom. It is also possible that large class size could increase the workload of the teacher which could, in turn, affect effective teaching and learning in the classroom. The findings of the current study are not in harmony with the findings of several authors (Biddle \& Berliner, 2000; Finn, 2002; Ready, 2008). Finn (2002) emphasised that when class size is more than 35, the quality of education is compromised. Similarly, Ready (2008) ascertained that the content of class size reduction can affect success in improving achievement. In furtherance, Biddle and Berliner (2000) in their study found that a smaller class is more beneficial for students from socio-economically disadvantaged backgrounds. It also appears from the results of the current study that textbook pupil ratio was better in urban schools and private schools as well for English, Mathematics and Integrated Science. In addition, other input factors were present in urban schools to a greater extent; these factors were poor for rural schools for the teaching of core subjects. Private schools reported the availability of other process factors than public schools. The findings of this study suggest that pupils in urban and private schools are more likely to perform better than their counterparts in rural and public schools. This is because pupils in urban and private schools will have access to sufficient textbooks to read both at school and home. Since practice makes perfect, such students are more likely to develop good vocabulary compared to their counterparts who lack textbooks in rural and public schools. The finding of this study is consistent with the findings of Stufflebeam (2004) who asserted that the input evaluation element recommends that learning needs and available strategies are considered as part of the initial planning process in the classroom.

\section{CONCLUSIONS AND RECOMMENDATIONS}

It can be concluded that JHS in the Central Region lack textbooks in Integrated Science, Mathematics and English Language. This resulted in more pupils using a few textbooks. Aside the textbooks, other essential facilities were absent. Parents were also found to play little role in monitoring the activities of their children in school. In a general view, some input factors were present while others were absent. This speaks to the fact that some major stakeholders have been redundant in playing their role in improving the quality of education. Due to the challenges with the absence of some input factors, there appear to be challenges in improving the process factors. Based on the findings of the study and the conclusions drawn, the following recommendations were made:

1. Headteachers should liaise with Ghana Education Service to provide adequate textbooks in Integrated Science, English language and Mathematics to reduce the gap in students to textbook ratio.

2. Ghana Education Service should provide sufficient infrastructure for the basic schools in the Central Region of Ghana. The infrastructure should centre on library facilities, science laboratory resources, and teaching and learning materials. 
3. Parents of pupils in JHS in the Central Region of Ghana are, by the findings of this study, encouraged to involve themselves in their ward's education. Headteachers and teachers should develop policies that will force parents to regularly visit the school to find out how their wards are doing in school.

\section{REFERENCES}

Akinbote, O. (2001). The Nigerian primary school teachers: Angels of instruction or devils of destruction. Nigerian Journal of Educational Philosophy, 7(1), 35-40.

Ampiah, J. G. (2010). Quality basic education in Ghana: Prescription, praxis and problems. Paper presented at the Experience Sharing Seminar, Accra, Ghana.

Ankoma-Sey, V. R., Asamoah, D., Quansah, F., \& Aheto, K. S. (2019). Factors affecting junior high school pupils' performance in Mathematics in Cape Coast Metropolis, Ghana. Staff and Educational Development International, 24(3), 128-138.

Attram, D. (2014). Assessing the delivery of education in Ghana: A case of Ejisu-Juaben Municipality. Unpublished Thesis, Department of Planning, Kwame Nkrumah University of Science and Technology, Kumasi.

Biddle, B. J., \& Berliner, D. C. (2000). Small class size and its effects. Educational Leadership, 59(5), 12-23.

Bruns, B., Mingat, A., \& Rakotomalala, R. (2003). A chance for every child: Achieving universal primary education by 2015. Washington, DC: World Bank.

Finn, J. D. (2002). Small classes in American schools: Research, practice, and politics. Phi Delta the Cape, 83(7), 551-560. Available at: https://doi.org/10.1177/003172170208300717.

Fobih, D., Akyeampong, K. A., \& Koomson, A. (1999). Ghana primary school development project: Final evaluation of project performance. Accra; Ghana: Ministry of Education.

Ghana Education Service. (2016). Education sector performance report. Accra, Ghana: Author.

Ghana Statistical Service. (2013). The 2010 population and housing census: Summary report of final results. Accra: Ghana Statistical Service.

Ministry of Education. (2011). Education sector performance report. Accra, Ghana: Ministry of Education.

Ministry of Education. (2016). Education sector performance report. Accra; Ghana: Ministry of Education.

Quansah, K. B. (2000). 1999 report on the administration of primary 6 criterion-referenced tests. Accra; Ghana: Ministry of Education.

Ready, D. D. (2008). Class-size reduction: Policy, politics, and implications for equity. Campaign for educational equity. New York: Teachers College, Columbia University.

Stufflebeam, D. L. (2004). The 21 st-century CIPP model: Origins, development, and use. In M. C. Alkin (Ed.), Evaluation roots (pp. 245-266). Thousand Oaks, CA: Sage.

UNESCO. (2005). Cultural heritage, creativity and education for all in Africa; for education in the arts and creativity in primary and secondary schools. Paper presented at the Regional Conference on Arts Education, Port Elizabeth, South Africa.

UNESCO. (2006). Cultural heritage, creativity and education for all in Africa; for education in the arts and creativity in primary and secondary schools. Paper presented at the Regional Conference on Arts Education, Port Elizabeth, South Africa.

Zainul-Deen, B. D. (2011). An assessment of Ghana's policy on quality education in the public senior high schools: A case study of Ahafo Ano North and South Districts. Doctoral Thesis Submitted to the College of Art and Built Environment, Kwame Nkrumah University of Science and Technology, Ghana.

Online Science Publishing is not responsible or answerable for any loss, damage or liability, etc. caused in relation to/arising out of the use of the content. Any queries should be directed to the corresponding author of the article. 